\title{
The temperature of caffeine administered during pregnancy and foetal morphometric parameters
}

\author{
M. Tomaszewski ${ }^{1}$, F. Burdan ${ }^{1}$, G. Olchowik ${ }^{2}$, M. Tomaszewska ${ }^{3}$ \\ ${ }^{1}$ Department of Human Anatomy, Medical University of Lublin, Poland \\ ${ }^{2}$ Department of Biophysics, Medical University of Lublin, Poland \\ ${ }^{3} 1^{\text {st }}$ Department of Radiology, Medical University of Lublin, Poland \\ [Received 16 December 2013; Accepted 22 January 2014]
}

Background: Caffeine is one of the most frequently ingested (at various temperatures) xenobiotics by people. A number of studies have confirmed the negative effect of high doses of caffeine ingested during pregnancy both for the mother and the developing foetus. The aim of this study was to evaluate the relationship between caffeine's toxicity on development and the administered solution's temperature.

Materials and methods: The research was conducted on rats. The fertilised females were randomly divided into two main groups: an experimental (E) and a control group (C). The experimental groups received caffeine (30 mg/day) in 10 (E1), 25 (E2) and $45^{\circ} \mathrm{C}$ (E3). The females in the control group were given water at the same temperature $\left(C_{1}, C_{2}\right.$ and $\left.C_{3}\right)$. On the $21^{\text {st }}$ day of pregnancy, the pregnant females were killed by decapitation using a specially prepared laboratory guillotine and were assessed morphometric parameters of foetuses.

Results and Conclusions: Based on this work showed that: the embryotoxic effect of caffeine was only confined to a reduction in the number of offspring; the greatest changes in the morphometric parameters occurred in foetuses whose mothers received caffeine at $10^{\circ} \mathrm{C}$; in the control groups, the greatest changes were observed in foetuses whose mothers were given water at $10^{\circ} \mathrm{C}$ during pregnancy. (Folia Morphol 2014; 72, 3: 347-352)

Key words: caffeine, morphometric parameters, pregnancy, foetus, resorbed foetuses, post-implantation mortality

\section{INTRODUCTION}

Caffeine is widespread throughout nature. In its processed form it is one of the most frequently ingested xenobiotics by people, including pregnant women. Some of the xenobiotics are routinely consumed chilled (Cola ${ }^{\circledR}$, Red Bull $\left.{ }^{\circledR}\right)$, at room temperature (chocolate, sweets), or hot (coffee, tea).

Caffeine is quickly and completely absorbed from the gastrointestinal tract, and is metabolised mainly in the liver (cytochrome P450). Its metabolism depends on gender, age, the organism's physiological state, oral contraceptives and smoking. In addition to the organism's ontogenic characteristics caffeine's pharmacokinetics are also affected by the time of day of its consumption [26]. A number of studies have shown that caffeine easily passes through biological membranes, including the blood-brain barrier, the placental barrier and can also enter the amniotic fluid, breast milk and semen [12, 19, 23, 39].

From the time when Nishimura and Nakai [24] demonstrated the adverse effect of caffeine on mice offspring, this substance became the focus of inter-

Address for correspondence: Dr M. Tomaszewski, Department of Human Anatomy, Medical University of Lublin, ul. Jaczewskiego 4, 
est for teratologists. Since then, a number of studies have confirmed the negative effect of high doses of caffeine ingested during pregnancy both for the mother and the developing foetus $[2,3,7,15,16$, $18,22,25,27,30,31$.

Despite extensive literature on the toxicity of methylxanthine, there are no reports evaluating the effects of caffeine on foetal development, with respect to temperature.

The aim of this study was to evaluate the relationship between caffeine's toxicity on development and the administered solution's temperature.

\section{MATERIALS AND METHODS}

The research was based on an animal experimental model, according to international guidelines for the assessment of developmental toxicity $[5,36]$, with the consent of the Ethics Committee at the Medical University of Lublin.

The research was conducted on white rats of the Wistar strain CRL: (WI) WUBR. All animals were in fixed environmental conditions with access to water and feed $[13,35]$ being freely available. Only standardised pelleted LSM ${ }^{\circledR}$ feed was used. Feed and water consumption was monitored on a daily basis.

After a 2 week acclimatisation period, the virgin females with a body mass $(238 \pm 24 \mathrm{~g})$ mated overnight with males (from $8 \mathrm{pm}$ to $8 \mathrm{am}$ ) in a ratio of $5: 2$. The presence of spermatozoa or a clot containing a mixture of semen and exfoliated vaginal epithelial in the morning vaginal swab was proof of successful copulation. The fertilised females were randomly divided into three experimental groups $\left(E_{1}, E_{2}\right.$, and $\left.E_{3}\right)$ and three control groups $\left(C_{1}, C_{2}\right.$, and $\left.C_{3}\right)$ each consisting of 8 rats. The day of fertilisation was considered to be the first day of pregnancy.

The study used caffeine (Caffeine anhydrous powder, Sigma-Aldrich Chemie GmbH, Germany) with a purity exceeding $99 \%$, administered in a dose of $30 \mathrm{mg} /$ day, which according to the data in the literature should interfere with the rat's prenatal development $[1,4,20]$.

The caffeine was dissolved in sterile distilled water at temperatures of $10^{\circ} \mathrm{C}\left(\mathrm{E}_{1}\right), 25^{\circ} \mathrm{C}\left(\mathrm{E}_{2}\right)$ and $45^{\circ} \mathrm{C}\left(\mathrm{E}_{3}\right)$ and a single daily dose of $2 \mathrm{~mL} / \mathrm{kg}$ body mass was administered intragastrically to the females from the $8^{\text {th }}$ to the $21^{\text {st }}$ day of pregnancy. The females in the control groups $\left(C_{1}, C_{2}\right.$ and $\left.C_{3}\right)$ received the same amount of water at the same temperature as the ones in the experimental groups $\left(E_{1}, E_{2}\right.$ and $\left.E_{3}\right)$. During the study the females' body mass was recorded every three days.

On the $21^{\text {st }}$ day of pregnancy, the pregnant females were killed by decapitation using a specially prepared laboratory guillotine. Death was caused by breaking the continuity of the spinal cord without damaging the continuity of the external layers.

After cutting the covering tissues of the abdominal cavity, the uterus with the foetuses were incised. The numbers of live, dead, and resorbed foetuses were counted. The post-implantation mortality rate (S) was calculated as follows:

$$
S \%=\frac{z-n}{z} \times 100
$$

where: $\mathrm{z}$ - number of implantations; $\mathrm{n}$ - number of live foetuses.

After incising the placentas and the foetal membranes, foetal vitality was assessed. A foetus which did not breathe, was motionless, did not react or its skin did not redden when touched was classified as dead.

The placentas were incised from the foetal membrane and the umbilical cord and were evaluated macroscopically, and then their mass was determined.

The foetuses were put to sleep using liquid nitrogen vapour, weighed and the crown rump length (which is considered to be the length of the foetus) as well as the maximum width of the head were measured [2]. The body mass index (BMI) was also calculated:

$$
B M I=\frac{m}{l^{2}}
$$

where: $m$ - weight of the foetus; I - length of the foetus.

\section{Statistical analysis}

The Shapiro-Wilk test was used to test the normality of distribution for other group characteristics. For parameters with a normal distribution the analysis of variance (ANOVA) was used, however, where this condition was not met the Kruskal-Wallis test was performed.

For statistical analysis the STATISTICA 7.0 (StatSoft Inc., USA) computer program was used. For all the tests the statistically significant differences were those, where the significance coefficient ( $p$ ) was less than 0.05 . 
Table 1. Average weight gain in pregnant female sin the experimental $\left(E_{1}, E_{2}, E_{3}\right)$ and control $\left(C_{1}, C_{2}, C_{3}\right)$ groups

\begin{tabular}{|c|c|c|c|c|c|c|c|}
\hline \multirow{2}{*}{$\begin{array}{l}\text { Day of } \\
\text { pregnancy }\end{array}$} & \multicolumn{6}{|c|}{ Group of animals } & \multirow{2}{*}{$\begin{array}{c}\text { The significance } \\
\text { of differences } \\
\text { between groups }\end{array}$} \\
\hline & $C_{1}$ & $E_{1}$ & $C_{2}$ & $\mathrm{E}_{2}$ & $\mathrm{C}_{3}$ & $E_{3}$ & \\
\hline 3 & $12.63 \pm 6.50$ & $6.75 \pm 3.06$ & $13.25 \pm 5.87$ & $14.56 \pm 8.58$ & $7.75 \pm 2.75$ & $9.29 \pm 5.76$ & $\begin{array}{l}P<0.05 \\
E_{1} \text { vs. } E_{2}\end{array}$ \\
\hline 6 & $24.25 \pm 8.14$ & $15.50 \pm 6.97$ & $26.60 \pm 5.29$ & $25.33 \pm 10.22$ & $19.50 \pm 3.00$ & $20.86 \pm 7.01$ & $\begin{array}{c}\mathrm{P}<0.05 \\
C_{1} \text { vs. } E_{1}, C_{1} \text { vs. } C_{2} \\
C_{2} \text { vs. } C_{3^{\prime}} E_{1} \text { vs. } E_{2}\end{array}$ \\
\hline 9 & $37.75 \pm 7.94$ & $24.38 \pm 11.31$ & $44.63 \pm 8.65$ & $39.11 \pm 15.09$ & $26.75 \pm 6.45$ & $32.00 \pm 9.29$ & $\begin{array}{c}P<0.05 \\
C_{1} \text { vs. } E_{1}, C_{1} \text { vs. } C_{2} \\
C_{2} \text { vs. } C_{3^{\prime}} E_{1} \text { vs. } E_{2}\end{array}$ \\
\hline 12 & $50.63 \pm 9.25$ & $37.38 \pm 18.65$ & $61.63 \pm 9.62$ & $53.30 \pm 19.42$ & $36.75 \pm 12.89$ & $39.57 \pm 12.68$ & $\begin{array}{c}P<0.05 \\
C_{2} \text { vs. } C_{3}, E_{1} \text { vs. } E_{2}\end{array}$ \\
\hline 15 & $60.13 \pm 10.42$ & $61.13 \pm 44.53$ & $77.38 \pm 8.45$ & $71.11 \pm 24.06$ & $46.75 \pm 20.37$ & $50.00 \pm 12.68$ & $\begin{array}{c}P<0.05 \\
C_{2} \text { vs. } C_{3^{\prime}} E_{1} \text { vs. } E_{2}\end{array}$ \\
\hline 18 & $71.38 \pm 12.48$ & $58.50 \pm 29.37$ & $99.13 \pm 8.75$ & $90.70 \pm 28.05$ & $58.00 \pm 25.52$ & $62.57 \pm 20.76$ & $\begin{array}{c}P<0.05 \\
C_{2} \text { vs. } C_{3}, E_{1} \text { vs. } E_{2} \\
E_{2} \text { vs. } E_{3}\end{array}$ \\
\hline 21 & $83.75 \pm 14.72$ & $64.88 \pm 31.06$ & $123.38 \pm 14.85$ & $111.82 \pm 31.32$ & $74.00 \pm 40.702$ & $74.71 \pm 26.72$ & $\begin{array}{c}\mathrm{P}<0.05 \\
\mathrm{C}_{2} \text { vs. } \mathrm{C}_{3^{\prime}} \mathrm{E}_{1} \text { vs. } \mathrm{E}_{2}\end{array}$ \\
\hline
\end{tabular}

Table 2. The number of resorbed foetuses, post-implantation mortality and the weight of placenta in groups exposed to caffeine $\left(\mathrm{E}_{1}, \mathrm{E}_{2}, \mathrm{E}_{3}\right)$ and control groups $\left(\mathrm{C}_{1}, \mathrm{C}_{2}, \mathrm{C}_{3}\right)$

\begin{tabular}{lccccccc}
\hline & \multicolumn{9}{c}{ Group of animals } & \multicolumn{2}{c}{$\begin{array}{c}\text { The significance } \\
\text { of differences } \\
\text { between groups }\end{array}$} \\
\cline { 2 - 9 } & $\mathbf{C}_{1}$ & $\mathbf{E}_{1}$ & $\mathbf{C}_{2}$ & $\mathbf{E}_{2}$ & $\mathbf{C}_{3}$ & $\mathbf{E}_{3}$ & NS \\
Number of resorbed foetuses & $0.92 \pm 0.63$ & $0.71 \pm 0.25$ & $0.35 \pm 0.13$ & $0.46 \pm 0.25$ & $0.87 \pm 0.75$ & $0.76 \pm 0.50$ & NS \\
Post-implantation mortality & $1.21 \pm 0.82$ & $0.72 \pm 0.26$ & $0.34 \pm 0.12$ & $0.43 \pm 0.23$ & $1.25 \pm 1.06$ & $1.01 \pm 0.67$ & $P<0.05$ \\
Weight of placenta [g] & $0.59 \pm 0.26$ & $0.31 \pm 0.14$ & $0.59 \pm 0.09$ & $0.43 \pm 0.07$ & $0.38 \pm 0.17$ & $0.43 \pm 0.12$ & $P$ \\
\hline
\end{tabular}

NS - insignificant statistically ( $p>0.05)$

\section{RESULTS}

In the population of rats taking part in the study (in both the control and experimental groups) no females died during the study. There were no significant differences in the amount of feed and water consumed between the groups.

Table 1 shows the average weight gain of the female rats during pregnancy. Statistically significant differences in weight gain were already observed from the $6^{\text {th }}$ day of gestation, both in the control and in the experimental groups. The greatest weight gains were found in the control group which was given water at $25^{\circ} \mathrm{C}$; these changes were statistically significant in relation to the control animals which were administered water at $45^{\circ} \mathrm{C}$. In the experimental groups the greatest weight gains were observed in females receiving caffeine also at $25^{\circ} \mathrm{C}$. However, these differences were statistically significant for animals which were administered caffeine at both $10^{\circ} \mathrm{C}$ or $45^{\circ} \mathrm{C}$. It should be emphasised that there were no significant differences in weight gains among females between the experimental groups $\left(E_{1}, E_{2}\right.$ and $\left.E_{3}\right)$ and their respective control groups.

The resorption count in individual litters was variable and ranged from 0 to 2 (Table 2 ), but these differences were not statistically significant. In addition, the post-implantation mortality rate did not differ significantly between the groups and ranged from 0 to 2.82 (Table 2).

The weight of the placenta (Table 2) was significantly lower in the females from the control group receiving water at $45^{\circ} \mathrm{C}$ as compared to other control 
Table 3. Morphometric parameters of foetuses in groups exposed to caffeine $\left(E_{1}, E_{2}, E_{3}\right)$ and control groups $\left(C_{1}, C_{2}, C_{3}\right)$

\begin{tabular}{|c|c|c|c|c|c|c|c|}
\hline \multirow{2}{*}{$\begin{array}{l}\text { Morphometric } \\
\text { parameters } \\
\text { of foetuses }\end{array}$} & \multicolumn{6}{|c|}{ Group of animals } & \multirow{2}{*}{$\begin{array}{c}\text { The significance } \\
\text { of differences } \\
\text { between groups }\end{array}$} \\
\hline & $C_{1}$ & $E_{1}$ & $C_{2}$ & $E_{2}$ & $C_{3}$ & $E_{3}$ & \\
\hline $\begin{array}{l}\text { Number of } \\
\text { foetuses } \\
\text { in the litter }\end{array}$ & $9.87 \pm 4.64$ & $12.00 \pm 1.07$ & $13.13 \pm 1.35$ & $12.37 \pm 3.06$ & $8.87 \pm 3.27$ & $9.37 \pm 3.54$ & $\begin{array}{c}P<0.05 \\
C_{2} \text { vs. } C_{3^{\prime}} C_{2} \text { vs. } E_{3} \\
C_{3} \text { vs. } E_{2}\end{array}$ \\
\hline $\begin{array}{l}\text { Foetal } \\
\text { weights [g] }\end{array}$ & $3.91 \pm 2.45$ & $2.43 \pm 1.66$ & $4.99 \pm 0.94$ & $4.65 \pm 1.14$ & $3.31 \pm 1.34$ & $2.43 \pm 0.92$ & $\begin{array}{c}P<0.05 \\
C_{2} \text { vs. } C_{3^{\prime}} C_{2} \text { vs. } E_{1} \\
C_{2} \text { vs. } E_{3^{\prime}} E_{1} \text { vs. } E_{2^{\prime}} \\
E_{2} \text { vs. } E_{3}\end{array}$ \\
\hline $\begin{array}{l}\text { Body } \\
\text { lengths [mm] }\end{array}$ & $33.36 \pm 7.14$ & $23.53 \pm 10.42$ & $36.45 \pm 2.23$ & $35.08 \pm 3.90$ & $25.54 \pm 9.64$ & $26.59 \pm 4.03$ & $\begin{array}{c}P<0.05 \\
C_{1} \text { vs. } C_{3^{\prime}} C_{1} \text { vs. } E_{1} \\
E_{1} \text { vs } C_{2^{\prime}} E_{1} \text { vs. } E_{2^{\prime}} \\
C_{2} \text { vs. } C_{3^{\prime}} C_{2} \text { vs. } E_{3} \\
E_{2} \text { vs. } E_{3^{\prime}} E_{2} \text { vs. } C_{3}\end{array}$ \\
\hline $\begin{array}{l}\text { Head } \\
\text { widths [mm] }\end{array}$ & $7.73 \pm 1.91$ & $5.63 \pm 2.71$ & $8.61 \pm 0.47$ & $9.00 \pm 0.99$ & $6.05 \pm 2.52$ & $6.75 \pm 1.28$ & $\begin{array}{c}\mathrm{P}<0.05 \\
\mathrm{C}_{1} \text { vs. } \mathrm{E}_{1}, \mathrm{E}_{1} \text { vs. } \mathrm{C}_{2} \\
\mathrm{E}_{1} \text { vs. } \mathrm{E}_{2^{\prime}} \mathrm{C}_{2} \text { vs. } \mathrm{C}_{3} \\
\mathrm{E}_{2} \text { vs. } \mathrm{E}_{3^{\prime}} \mathrm{E}_{2} \text { vs. } \mathrm{C}_{3}\end{array}$ \\
\hline $\begin{array}{l}\text { Foetal body } \\
\text { mass index } \\
{\left[\mathrm{kg} / \mathrm{m}^{2}\right]}\end{array}$ & $3.13 \pm 0.93$ & $5.26 \pm 2.96$ & $3.72 \pm 0.24$ & $3.67 \pm 0.46$ & $7.07 \pm 4.73$ & $3.29 \pm 0.34$ & $\begin{array}{c}P<0.05 \\
C_{1} \text { vs. } C_{3^{\prime}} C_{2} \text { vs. } C_{3} \\
E_{2} \text { vs. } C_{3^{\prime}} E_{3} \text { vs. } C_{3}\end{array}$ \\
\hline
\end{tabular}

groups. Significant differences were also found between the groups in which females received water or caffeine at $10^{\circ} \mathrm{C}$. Asymmetric placental fusion was observed in only 1 case, in a litter exposed to caffeine at $25^{\circ} \mathrm{C}$. Apart from this, no other macroscopically visible abnormalities were observed.

In the studied rat offspring population, the smallest number of foetuses were found in the groups which were administered water or caffeine at $45^{\circ} \mathrm{C}$. These changes were significant compared to animals receiving water at $25^{\circ} \mathrm{C}$. However, there were no significant differences in the number of foetuses between the experimental groups and the corresponding control groups (Table 3).

The greatest foetal weights in the experimental and control groups occurred in those groups where the pregnant females received water or caffeine at $25^{\circ} \mathrm{C}$ (Table 3) whilst the lowest in those groups which received caffeine at $10^{\circ} \mathrm{C}$ or $45^{\circ} \mathrm{C}$. These differences were statistically significant in both the $C_{2}$ and $E_{2}$ groups. Significant differences in foetal weights were also observed between the control groups, in which the females received water at $25^{\circ} \mathrm{C}$ or $45^{\circ} \mathrm{C}$ (Table 3 ).

The longest body lengths were observed in foetuses whose mothers received water or caffeine at $25^{\circ} \mathrm{C}$, and the shortest in those groups, in which the females were given caffeine at either $10^{\circ} \mathrm{C}$ or $45^{\circ} \mathrm{C}$ (Table 3). These changes were statistically significant for both the control group $\mathrm{C}_{2}$, as well as for the experimental group $\mathrm{E}_{2}$. Significant changes in foetal body length between control groups $C_{2}$ and $C_{3}$ were also observed, as well as between the control group and the experimental group receiving water or caffeine at $10^{\circ} \mathrm{C}$.

The maximum head widths (Table 3 ) were observed in foetuses whose mothers received water or caffeine at $25^{\circ} \mathrm{C}$. Significant differences were observed between the experimental group $\mathrm{E}_{2}$, and the remaining two groups, in which the females were given caffeine at either $10^{\circ} \mathrm{C}$ or $45^{\circ} \mathrm{C}$. Statistically significant differences were also found between the control groups, in which water was given at $25^{\circ} \mathrm{C}$ or $45^{\circ} \mathrm{C}$, as well as between the group receiving caffeine at $10^{\circ} \mathrm{C}$, compared to the appropriate control group $\left(C_{1}\right)$.

Table 3 shows the average foetal BMI values for each group of rats. The highest BMI values were observed in the group of foetuses whose mothers received water at $45^{\circ} \mathrm{C}\left(\mathrm{C}_{3}\right)$. However, in the remaining two control groups $\left(\mathrm{C}_{1}\right.$ and $\left.\mathrm{C}_{2}\right)$ the $\mathrm{BMI}$ values were significantly lower. Also, significantly lower $\mathrm{BMI}$ values were observed in foetuses from mothers given caffeine at $25^{\circ} \mathrm{C}$ or $45^{\circ} \mathrm{C}$ compared to the control group $C_{3}$. 


\section{DISCUSSION}

Caffeine is a compound which passes through the placental barrier. Experimental research has shown that in high doses it can cause an embryotoxic effect. In smaller doses it reduces the weight gain of pregnant females, reduces the number of offspring per litter as well as foetal morphometric parameters (it interferes with intrauterine growth) [4, 20, 21, 28, 29, 34, 37].

Elmazar et al. [4], by giving mice caffeine in doses of $150 \mathrm{mg} / \mathrm{kg}$ and $250 \mathrm{mg} / \mathrm{kg}$ in drinking water and in doses of $50 \mathrm{mg} / \mathrm{kg}$ and $150 \mathrm{mg} / \mathrm{kg}$ in feed, between the $5^{\text {th }}$ and $18^{\text {th }}$ day of gestation, showed that the increase in body weight of females receiving a lower dose of caffeine was comparable to the control group, but was significantly lower after administering the higher dose. The weight of the offspring was significantly lower in the group receiving the higher dose of caffeine.

Similar results were also obtained by Smith et al. [29], who administered caffeine in doses of $10 \mathrm{mg} / \mathrm{kg}$ and $100 \mathrm{mg} / \mathrm{kg}$ in single or four subdivided doses. The weight gain of the pregnant females was lower in the groups receiving $100 \mathrm{mg} / \mathrm{kg}$ caffeine, irrespective of whether it was administered as a single dose or not, as well as in the group receiving $10 \mathrm{mg} / \mathrm{kg}$ in subdivided doses. In addition, a reduction in the placental weight as well as the number of offspring was noted in the groups of animals.

Similar results have been reported by other researchers: West et al. [34] (caffeine administered in doses of $50 \mathrm{mg} / \mathrm{kg}$ and $75 \mathrm{mg} / \mathrm{kg}$ body weight between the $3^{\text {rd }}$ and $19^{\text {th }}$ day of gestation), Muther [20] (caffeine administered in a dose of $100 \mathrm{mg} / \mathrm{kg}$ body weight during pregnancy), Wilkinson and Pollard [37] (caffeine administered in a dose of $25 \mathrm{mg} / \mathrm{kg}$ on the $8^{\text {th }}$ and $9^{\text {th }}$ day of gestation) and Nakamoto et al. [21] (caffeine administered in dosses between $0.5-2 \mathrm{mg} / \mathrm{kg}$ between the $8^{\text {th }}$ and $22^{\text {nd }}$ day of gestation). They found that caffeine in these doses administered to pregnant females results in foetuses being lighter.

Scott [28] administered caffeine intraperitoneally to pregnant mice in doses of $80,100,150,175,200$, 225 and $250 \mathrm{mg} / \mathrm{kg}$. The embryotoxic effect only occurred after the highest caffeine dose. In the group of animals receiving intermediate doses, there was a slight increase in the foetal resorption rate.

Prenatal studies on Macaca fasciluris monkeys showed that receiving caffeine during pregnancy reduces weight and body length of newborns [8-10]. Female rats receiving caffeine in a dose between 10 and
$30 \mathrm{mg} / \mathrm{kg}$ had a higher percentage of miscarriages and stillborn foetuses. The female body parameters were normalised within 30 days, whilst in males, this process lasted nearly a year. The offspring of mothers receiving caffeine showed behavioural changes they suckled longer and learned more slowly.

It should be emphasised that it is still difficult to determine the relationship between caffeine consumption and low birth weight of newborns in pregnant women. This is due to the fact that often mothers drinking large quantities of coffee are at the same time dependent on tobacco or alcohol - factors that also slow down intrauterine development [8]. Fortier et al. [6], demonstrated an increased (5.2\%) risk of giving birth to an underweight baby, if the daily intake of caffeine during pregnancy was greater than $300 \mathrm{mg} /$ day, compared to a $1.3 \%$ risk in mothers who did not consume caffeine at all. The difference in weight between the two groups of newborns was $105 \mathrm{~g}$. These findings confirm Watkinson's and Fried's [32] previous observations. Among the 286 women consuming more than $300 \mathrm{mg}$ of caffeine daily during pregnancy, babies were born with a lower birth weight.

Infante-Rivard et al. [14] investigated the relationship between caffeine consumption and spontaneous miscarriages among women hospitalised after a miscarriage. Consuming caffeine in doses greater than $321 \mathrm{mg} /$ day, prior to conception, increased the rate of a miscarriage. Caffeine in doses less than $162 \mathrm{mg} /$ day during pregnancy did not correlate with an increased risk of miscarriage.

Other authors have also made similar observations. Wen et al. [33] showed that the rate of a spontaneous miscarriage increased among women who consumed caffeine in doses of $300 \mathrm{mg} /$ day and did not complain of nausea. In groups of 75 women who did not feel nausea, $29.6 \%$ had miscarriages whilst for women who complained of nausea miscarriages only occurred in $7.2 \%$ of cases.

\section{CONCLUSIONS}

Products containing caffeine are consumed in a $4-60^{\circ} \mathrm{C}$ temperature range (Yang et al. 2007 [38]). In literatures, there are no reports evaluating the effects of caffeine on foetal development, with respect to temperature. Among the hypotheses supporting this relationship, are mentioned different genotype variants of cytochrome P4501A2 (in people with rapid metabolism of caffeine, may constitute a risk group for bone loss induced by coffee) (Hallström 
et al., 2010 [11]) or the presence of new, unknown endogenous compounds caffeine (e.g. mono-nitroso-caffeidine, an asymmetric di-nitrosamine and caffeidine nitroso-N-nitrosamide, which in vitro have potential relevance in the aetiology of oesophageal and gastric cancers) (Kumar et al., 1992 [17]), which deepen the teratogenic effect.

\section{REFERENCES}

1. Burdan F, Madej B, Wójtowicz Z, Maciejewski R, Radzikowska E (2000) The effects of short-time caffeine administration on skeleton development in Wistar rats. Folia Morphol, 59: 91-95.

2. Christian MS (2001) Test methods for assessing female reproductive and developmental toxicology. In: Hayes AW ed. Principles and method of toxicology. 4 Ed. Taylor and Francis, Philadelphia, pp. 1301-1381.

3. Christian MS, Brent RL (2001) Teratogen update: evaluation of the reproductive and developmental risks of caffeine. Teratology, 64: 51-78.

4. Elmazar MMA, McElhatton PR, Sullivan FM (1982) Studies on the teratogenic effects of different oral preparations of caffeine in mice. Toxicology, 23: 57-71.

5. EMEA 2000. Note for guidance on repated dose toxity. CMP/SWP/1042/99. http://www.emea.eu.int/.

6. Fortier I, Marcoux S, Beaulac-Baillargeon L (1993) Relation of cafeine intake during pregnancy to intrauterine growth retardation and preterm birth. Am J Epidemiol, 137: 931-940.

7. Giannelli M, Doyle P, Roman E, Pelerin M, Hermon C (2003) The effect of caffeine consumption and nausea on the risk of miscarriage. Paediatr Perinat Epidemiol, 17: 316-323.

8. Gilbert SG, Deborah CR (1991) Somatic development of the infant monkey following in utero exposure to caffeine. Fundam Toxicol, 17: 454-465.

9. Gilbert SG, Rice DC, Reuhl KR, Stavric B (1998) Adverse pregnancy outcome in the monkey (Macaca fascicularis) after chronic caffeine exposure. J Pharmacol Exp Ther, 245: 1048-1053

10. Gilbert SG, So Y, Klassen R, Geoffroy S, Stavric B, Rice D (1986) Elimination of chronically consumed caffeine in the pregnant monkey (Macaca fascicularis). J Pharmacol Exp Ther, 239: 891-897.

11. Hallström $H$, Melhus $H$, Glynn A, Lind L, Syvänen A-Ch, Michaëlsson K (2010) Coffee consumption and CYP1A2 genotype in relation to bone mineral density of the proximal femur in elderly men and women: a cohort study. Nutrition and Metabolism, 7: 12.

12. Hart AD, Grimble RF (1990) Effect of methylxanthines on lactational performance of rats. Ann Nutr Metab, 34: 297-302.

13. ICH (2000) ICH Harmonised tripartite guideline. Maintenance of the ICH guideline on toxicity to male fertility. An addendum to ICH tripartite guideline on detection of toxicity to reproduction for medicinal products. http:// www.ifpma.org/ich1.html.

14. Infante-Rivard C, Fernandez A, Gauthier R, David M, Rivard GE (1993) Fetal loss associated with caffeine intake before and during pregnancy. JAMA, 270: 2940-2943.

15. Kujawa-Hadryś M, Tosik D, Bartel H (2010) Changes in thickness of each layer of developing chicken cornea after administration of caffeine. Folia Histochem Cytobiol, 48: 273-277.

16. Kujawa-Hadryś M, Tosik D, Bartel H (2010) Ultrastructural changes in the developing chicken cornea following caffeine administration. Folia Histochem Cytobiol, 48: 371-376.

17. Kumar R, Mende P, Wacker C-D, Spiegelhalder B, Preussmann R, Siddiqi M (1992) Caffeine-derived N-nitroso compounds - I: nitrosatable precursors from caffeine and their potential relevance in the etiology of oesophageal and gastric cancers in Kashmir, India. Carcinogenesis, 13: 2179-2182.
18. Li ZG, Shimada Y, Sato F, Maeda M, Itami A, Kaganoi J, Komoto I, Kawebe A, Imamura M (2003) Promotion effects of hot water on $\mathrm{N}$-nitrosomethylbenzylamine-induced esophageal tumorigenesis in F344 rats. Oncol Rep, 10: 421-426.

19. McLean C, Graham TE (2002) Effects of exercise and thermal stress on caffeine pharmacokinetics in men and eumenorrheic women. J Appl Physiol, 93: 1471-1478.

20. Muther TF (1988) Caffeine and reduction of fetal ossification in the rat: fact or artifact? Teratology, 37: 239-247.

21. Nakamoto T, Grant S, Yazdani M (1989) The effect of maternal caffeine intake during pregnancy on mineral contents of rat bone. Res Exp Med, 189: 275-280.

22. Nawrot $P$, Jordan S, Eastwood J, Hugenholtz A, Feeley M (2003) Effects of caffeine on human health. Food Addit Contam, 20: 1-30.

23. Nikolic J, Bjelakovic G, Stojanovic I (2003) Effect of caffeine on metabolizm of L-arginine in the brain. Mol Cell Biochem, 244: 125-128.

24. Nishimura H, Nakai K (1960) Congenital malformations in offspring of mice treated with caffeine. Proc Soc Exp Med, 104: 140-142.

25. Olchowik G, Chadaj-Polberg E, Tomaszewski M, Polberg M, Tomaszewska M (2011) The influence of caffeine on the biomechanical properties of bone tissue Turing pregnancy in a population of rats. Folia Histochem Cytobiol, 49: 504-511.

26. Pelissier-Alicot AL, Schreiber-Deturmeny E, Simon N, Gantenbein M, Bruguerolle B (2002) Time-of-day dependent pharmacodynamic and pharmacokinetic profiles of caffeine in rats. Naunyn Schmiedebergs Arch Pharmacol, 365: 318-325.

27. Ratnasooriva WD, Fernando TS (2009) Effects of Sri Lankan black tea (Camellia sinensis L.) on pregnancy of rats. Basic Clin Pharmacol Toxicol, 105: 361-365.

28. Scott W (1983) Caffeine-induced limb malformation: description of malformation and quantitation of placental transfer. Teratology, 28: 427-435.

29. Smith SE, McElhatton PR, Sullivan FM (1987) Effects of administering caffeine to pregnant rats either as a single daily dose or as divided doses four times a day. Food Chem Toxicol, 25: 125-133.

30. Soellner DE, Grandys T, Nunez JL (2009) Chronic prenatal caffeine exposure impairs novel object recognition and radial arm maze behaviors in adult rats. Behav Brain Res, 14: 191-199.

31. Tomaszewski M, Olchowik G, Tomaszewska M, Burdan $F$ (2012) Use of X-ray microprobe to diagnose bone tissue demineralization after caffeine administration. Folia $\mathrm{Hi}$ stochem Cytobiol, 50: 436-443.

32. Watkinson B, Fried PA (1985) Maternal caffeine use before, during, and after pregnancy and effects upon offspring. Neurobehav Toxicol Teratol, 7: 9-17.

33. Wen W, Shu I, Xia O, Jacobs D, Brown J (2001) The association of maternal caffeine consumption and nausea with spontaneous abortion. Epidemiology, 12: 38-42.

34. West GL, Sobotka TJ, Brodie RE, Beier JM, O'Donnell MW Jr. (1986) Postnatal neurobehavioral development in rats exposed in utero to caffeine. Neurobehav Toxicol Teratol, 8: 29-43.

35. White WJ (2001) The use of laboratory animals in toxicologic research. In: Hayes AW ed. Principles and method of toxicology. 3 Ed. Taylor and Francis, Philadelphia, pp. 774-818.

36. WHO (2001) World Health Organization. Principles for evaluating health risks to reproduction associated with exposure to chemicals. Environ Health Criteria, 225: 1-185.

37. Wilkinson J, Pollard I (1994) In utero exposure to caffeine causes delayed neural tube closure in rat embryos. Teratog Carcinog Mutagen, 14: 205-211.

38. Yang DJ, Hwang LS, Lin JT (2007) Effects of different steeping methods and storage on caffeine, catechins and gallic acid in bag tea infusions. J Chromatogr A, 1156: 312-320.

39. Zancheta R, Possi AP, Planeta CS, Marin MT (2012) Repeated administration of caffeine induces either sensitization or tolerance of locomotor stimulation depending on the environmental context. Pharmacol Rep, 64: 70-77. 